\title{
COMPRESSION OF THE OPTIC NERVE BY A FUSIFORM ANEURYSM OF THE CAROTID ARTERY*
}

\author{
BY \\ ADOLFO LEY \\ From the Neurosurgical Clinic of the University of Barcelona
}

The symptomatology of congenital saccular and arteriovenous aneurysms as well as of other vascular abnormalities of the brain have been carefully described by a number of authors, and there seems to be little to add to this interesting chapter of surgical neurology. However, there is a type of vascular lesion characterized by fusiform enlargement, generally bilateral, of the subclinoid portion of the carotid artery which is less well known (Fig. 1). This lesion was first described, so far as we know, by Adson, who published two of these cases in 1942 . $\mathrm{He}$ does not consider it a true aneurysm and regards it as being due to hardening of the wall and abnormal internal rotation of the intracranial carotid. Later Tassman (1944) published a similar case and Taptas (1948), in an article devoted to the dilatations and enlargements of the intracranial carotid, published another case of the same nature (Case 4).

We have seen another five cases. In four of them the lesions were verified surgically, and one of these subsequently came to necropsy. A survey of this material convinces us that the clinical picture, fundamentally characterized by visual symptoms, is sufficiently definite to be considered as a syndrome.

The clinical manifestations occur in middle life, and in the recorded cases males are slightly in the majority. In four of our cases and in Adson's. second, the patients showed moderate arterial hypertension, although in our first case and in Adson's second, only the diastolic pressure was found to be elevated. The renal function was satisfactory in general, except in our third case in which it was slightly impaired.

The symptomatology is predominantly visual and characterized in general by its long duration : the longest in our case was 16 years, although in some of the cases described by Adson (1942) and Tassman (1944) and in our own fifth case, the duration was less than a year. The beginning is usually rather sudden, affecting at first only one eye, generally the

\footnotetext{
* Read before the "Sociedad Luso-Española de Neurocirugia," Valencia, May 1949.
}

left. In three of the eight cases the visual symptoms were preceded by trivial head injuries. The initial diagnosis was usually " optic neuritis" of retrobulbar type, but we have only once had the opportunity of observing the ophthalmoscopic picture in the initial phase, when there was no doubt that there was papillœdema. The subjective visual symptoms consist of a diminution of the visual acuity, which the patient describes as "veiling," "blurring," or partial blindness. In the case reported by Taptas, the visual blurring was transitory and was accompanied by paroxysmal headaches. Whether the beginning is sudden or slowly progressive, after a considerable fall in the visual acuity in one eye, the blurring becomes stationary for a time. The visual symptoms are usually accompanied by headaches, generally localized in the frontal and orbital regions The headache is generally of a " sore " type and only occasionally is it very intense. However in Taptas's case it was paroxysmal and was accompanied by vasomotor changes in the face.

After a variable period, even 15 years in our third case, reduction of vision occurs in the remaining eye. At this stage there is usually an intense reduction in the visual acuity with changes in the fundi and visual fields which seem to be of a characteristic type. In regard to the fundi, there is usually papillœdema in the one most recently affected. In one of our cases there were even small retinal hæmorrhages (Fig.2, Case 1). In other câses, like Adson's second, that of Taptas, and our third, the papillœdema was associated with some pallor of the disc. In the eye first affected the appearance is usually that of a primary atrophy, the combination thus presenting the features of the Foster-Kennedy syndrome (Fig. 2A). Tassman (1944) was the first to recognize the existence of this syndrome in the lesions which we are discussing. In our fifth case we observed a very curious ophthalmoscopic picture consisting of œdema in the lower halves of both discs and an atrophic pallor in the upper halves. (Fig. 2, Case 5).

The failure of vision is usually more pronounced in the eye first affected, but in one of our cases (No. 3) the reverse occurred. 
Seat of the arterial enlargement

Intradural artery
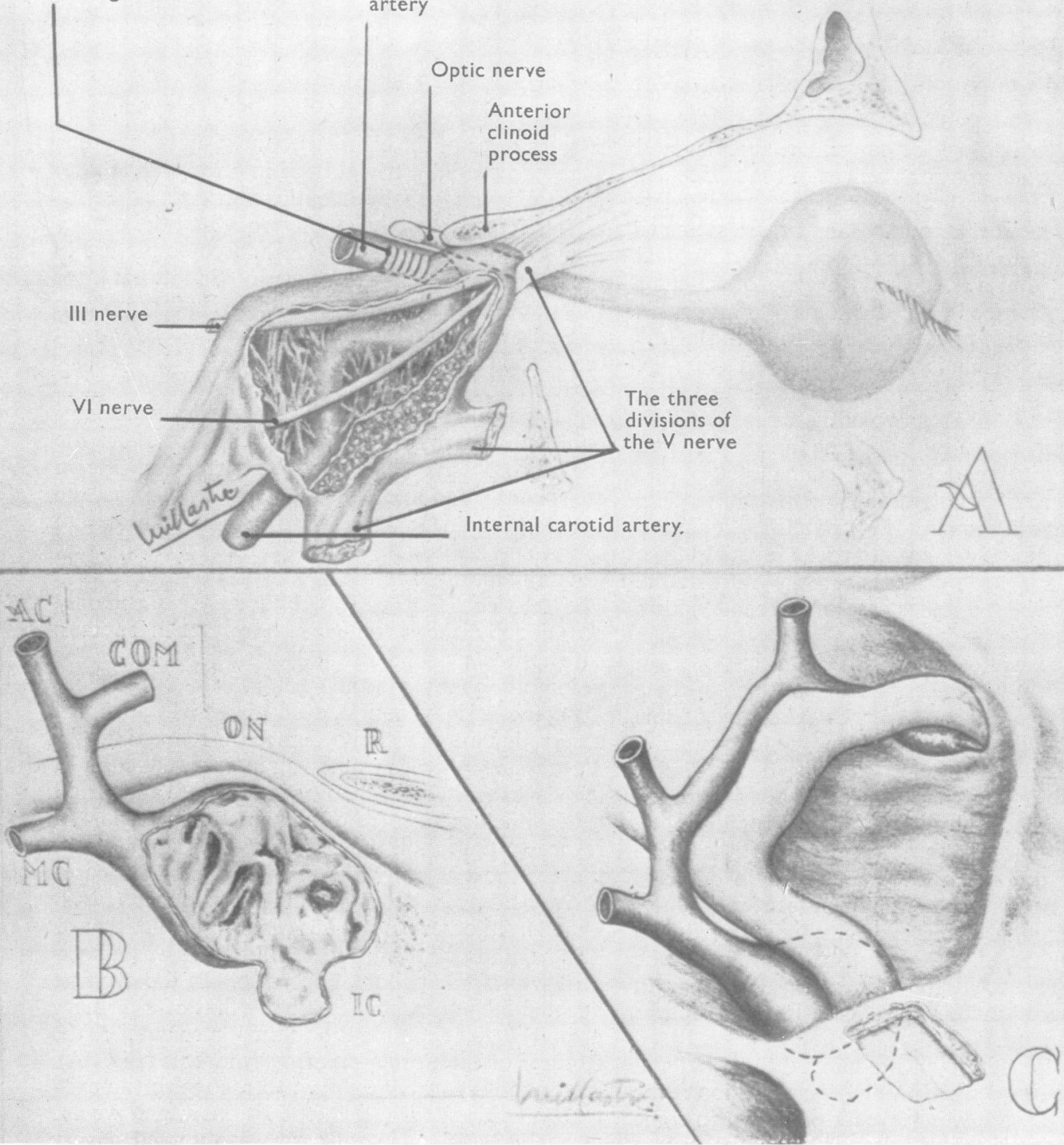

FIG. 1.-A. Diagram showing the situation of the vascular lesion and its relationship with the optic nerve and some other basa structures. B. Cross section of the vascular lesion showing the compression of the optic nerve against the roof of the optie. channel. C. Artist's conception of the vascular lesion. 


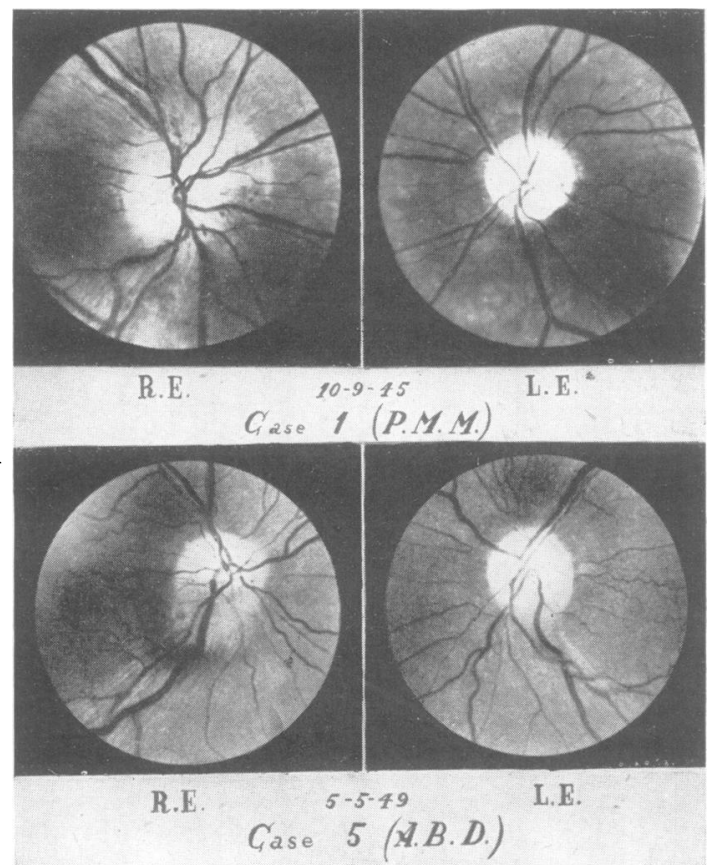

As regards the visual fields, there is generally concentric constriction, but in our cases there was a marked tendency to lower quadrant defects in the beginning, the nasal half being first affected (Fig. 4). Later there may even be a horizontal hemianopia (Fig. 4, C and D). In the eye more recently affected there was concentric constriction, although in general this defect seems to predominate in the lower fields (Fig. 4). The central vision is usually spared for a long time.

These findings do not coincide with the observations of Adson (1942), in which the defects were bi-nasal hemianopia in one case, and large central scotoma in the other. However, one must take into account that in his cases the lesions were very advanced. The predominance of field defects in the lower quadrants seems to be quite understandable,

Fig. 2.-Retinograph of Case 1 showing the typical Foster-Kennedy syndrome. Minute hæmorrhages can be seen in the right eye. Retinograph of Case 5 showing the peculiar changes, namely, œdema of the lower halves and atrophic pallor of the upper parts of both discs.

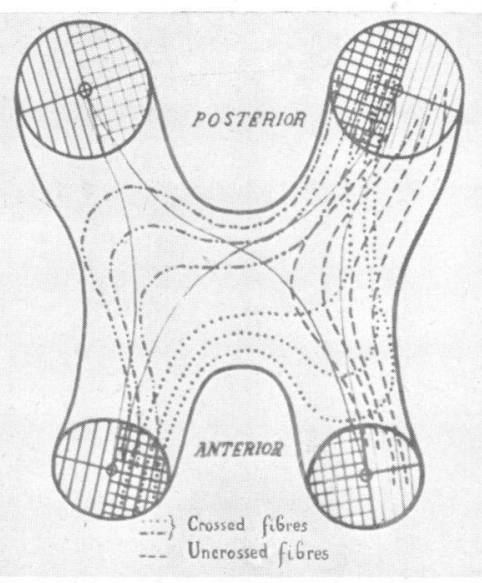

The distribution of visual nerve fibres after Willbrand and Saenger (redrawn and simplified from Traquair (1942)).

MNS, Macular Upper Nasal fibres ; MNI, Macular Lower Nasal ; MTS, Macular Upper Temporal ; MTI, Macular Lower Temporal ; PNS, Peripheral Upper Nasal ; PNI, Peripheral Lower Nasal ; PTS, Peripheral Upper Temporal ; PTI, Peripheral Lower Temporal.

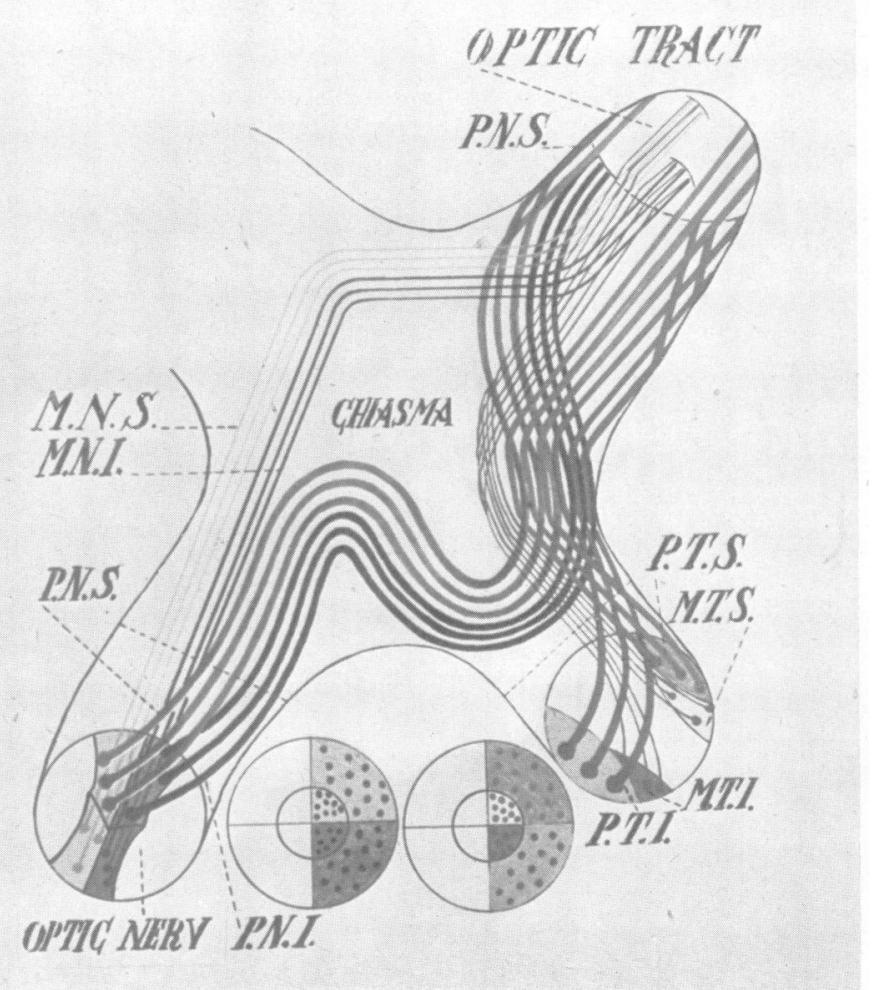

FIG. 3.-Diagram showing the distribution of visual nerve fibres in the optic nerves, chiasma, and optic tracts (redrawn and simplified from Malbran (1936)). 

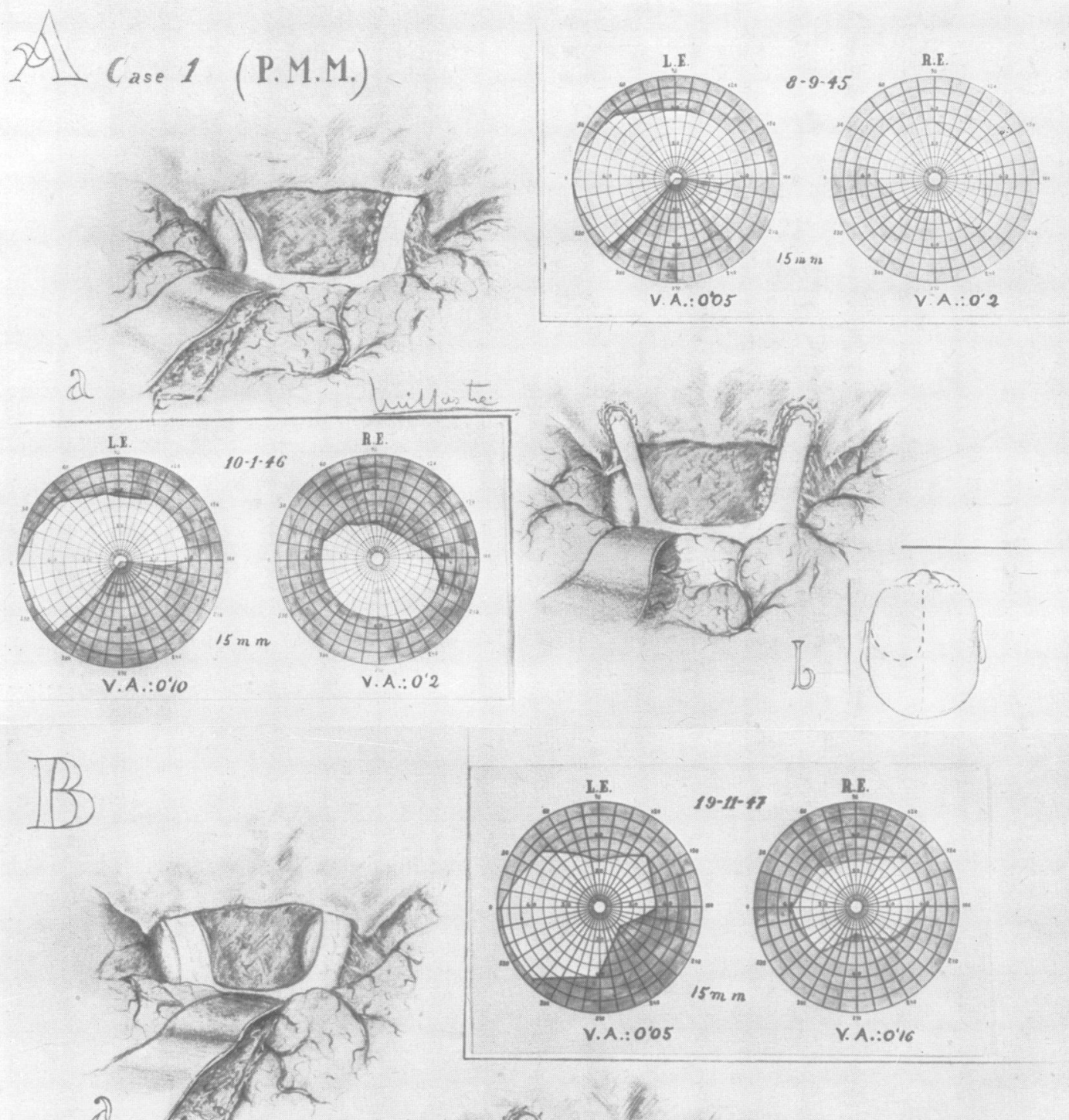

a

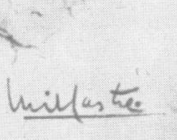

Giase 2 (J.Gh.A.)
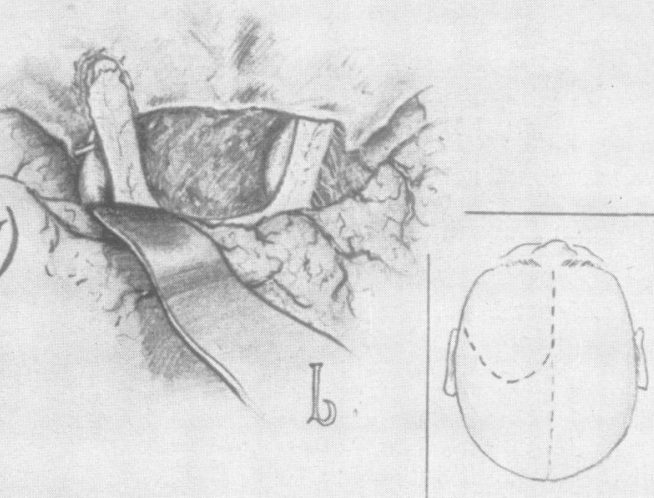

FIG. 4.-Sketches of Cases 1 and 2 showing the lesions found at operation, and the surgical procedure used in each case. The visual fields are also represented. 
U
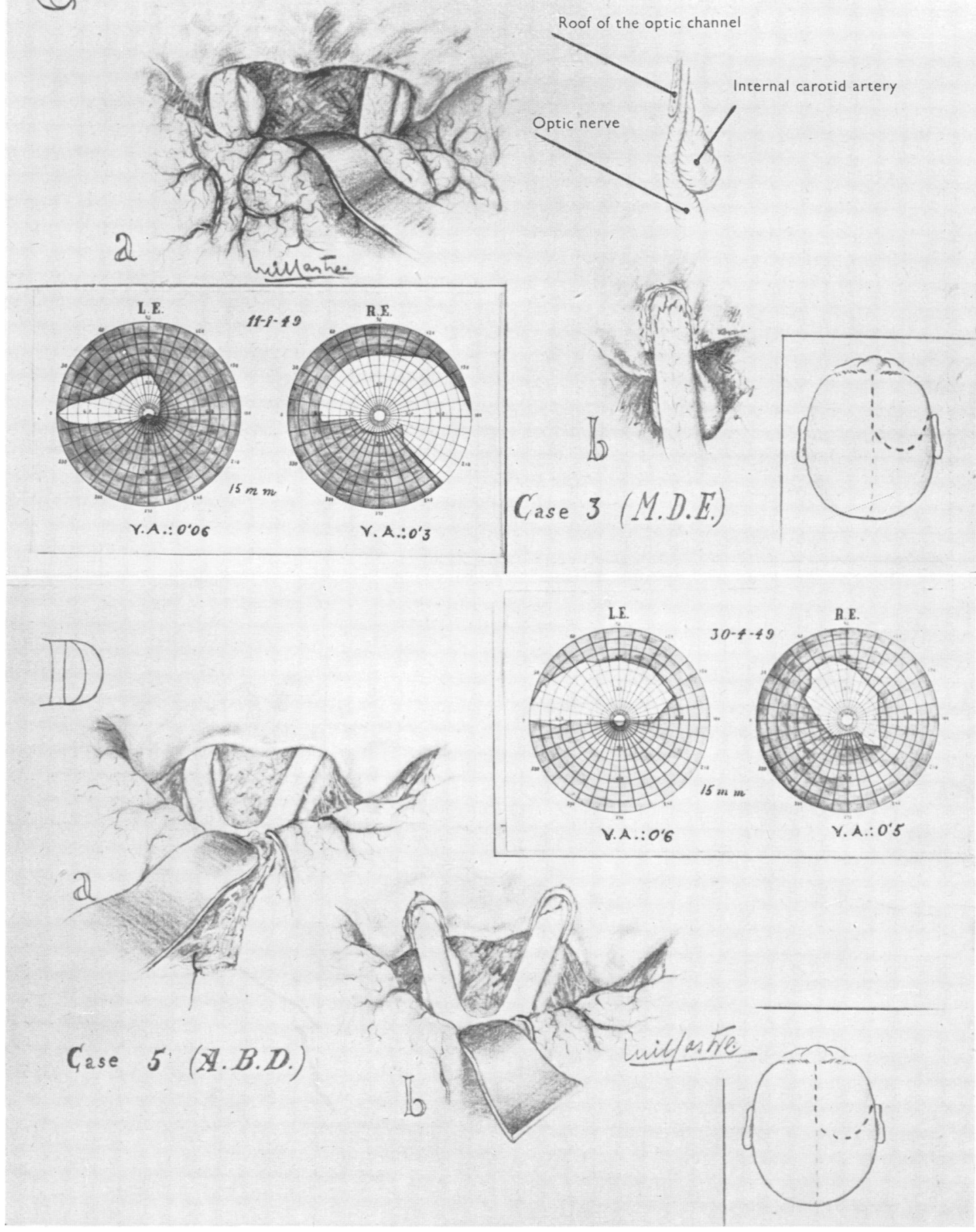

Fig. 4.-Sketches of Cases 3 and 5 showing the lesions found at operation, and the surgical procedure used in each case. The visual fields are also represented. 

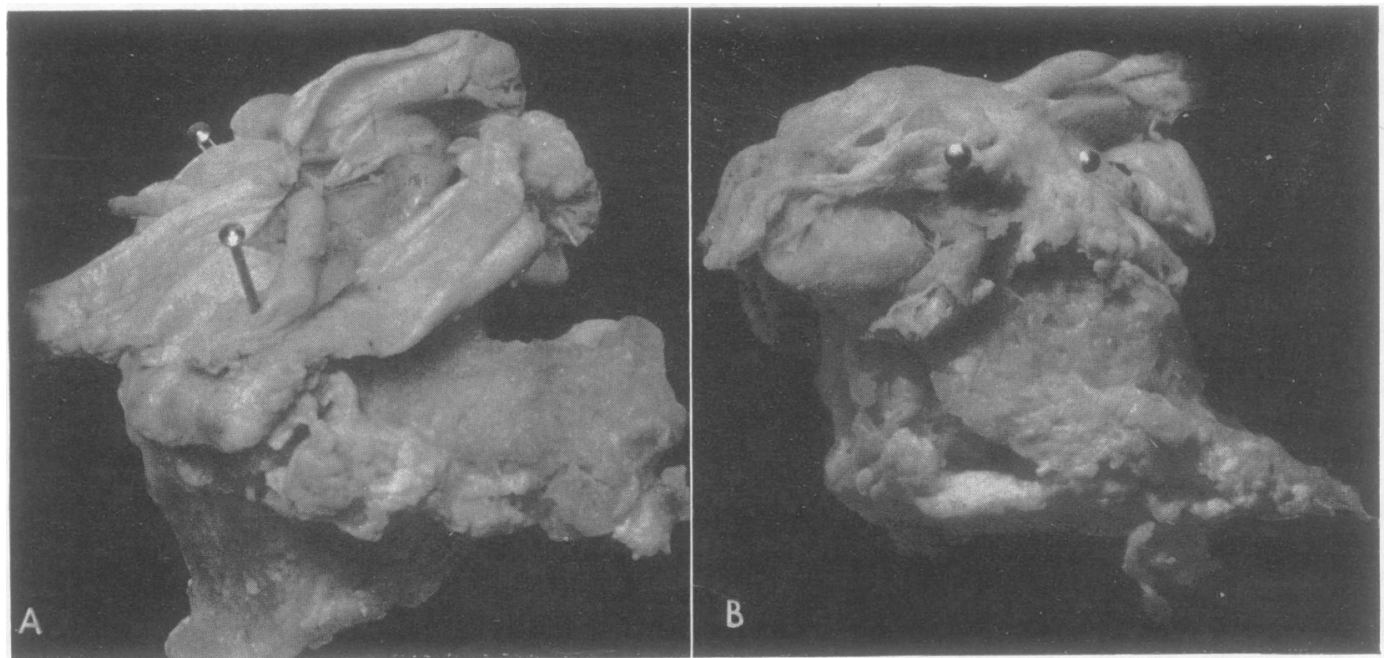

FIG. 5.-Lateral aspects of the dissected sphenoidal body in Case 3. The wall of the cavernous sinus has been opened in order to show both internal carotid arteries. In 5A the right carotid appears almost normal in size and shape, but in 5B the left carotid shows a marked enlargement. The third nerve has been retracted and pinned in order to show the vessels. The sixth nerve is clearly shown crossing the intracavernous carotid in $5 \mathrm{~A}$.
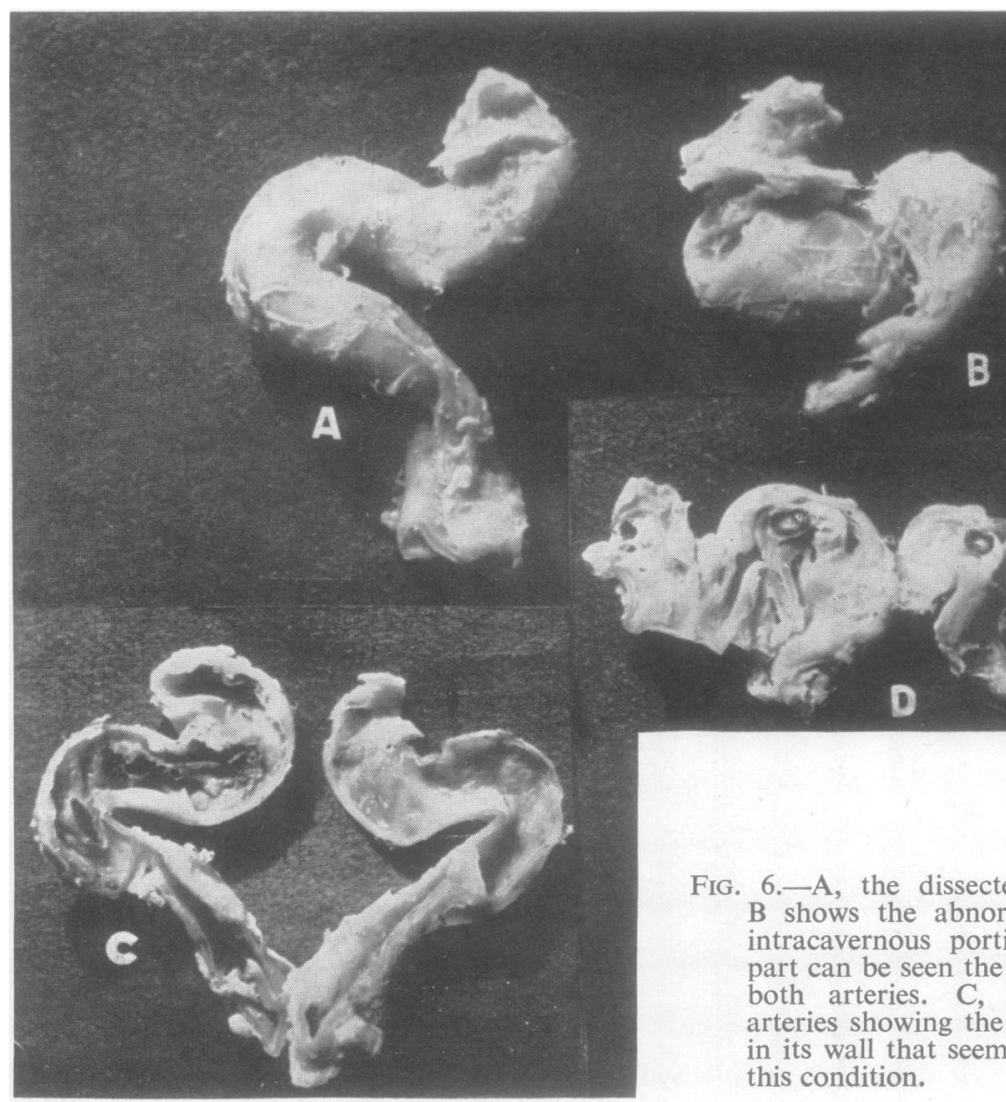

B
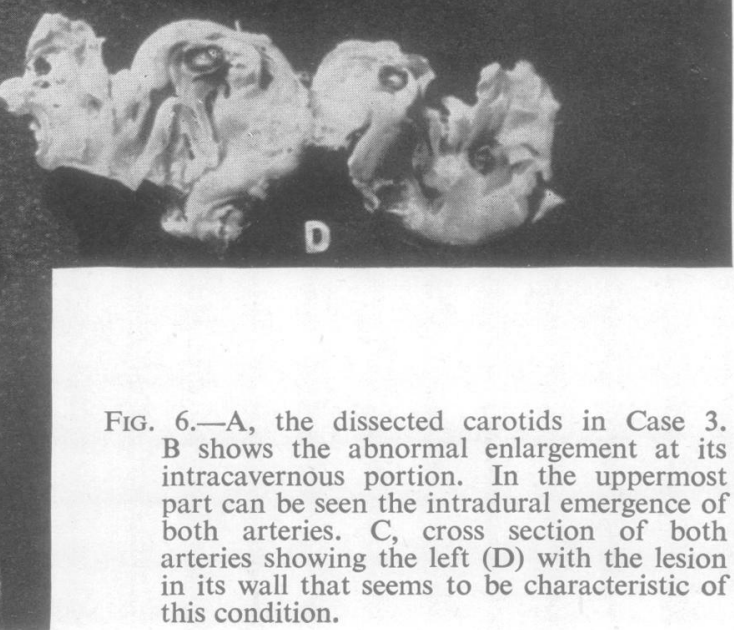
this condition. 
taking into account the mechanism of compression of the optic nerves, which in the lesion we are discussing acts upwards against the dorsal edge of the roof of the optic canal and its dural prolongation (Fig. 1C). It is also understandable for the same reason that the macular fibres should be unaffected at the beginning (Fig. 3). These clinical findings seem thus far to confirm the accuracy of Malbran's (1936) systemization of the optic way, which differs from that of Willbrand and Saenger.

The extrinsic and intrinsic ocular muscles are generally unaffected, which is also understandable as the occulomotor nerves are in no relation to the lesion (Fig. 1A). In one of our cases (the second), there was a congenital ocular palsy, affecting the sixth nerve. This was due to the existence of another carotid dilatation in the intracavernous portion of the artery, which was revealed in the necropsy (Figs. 5 and 6). Therefore this case enters the more extensive group of carotid anomalies called" serpentine aneurysm," which have been studied by Taptas (1948) and others (Moniz, 1934 ; Saphir, 1935). The pupils are usually dilated, especially that of the eye most affected, the photomotor reactions being affected in proportion to the degree of visual failure.

The course was without fever and the serological examinations in our cases did not reveal any alterations of an inflammatory character, specific or otherwise. The blood-count and sedimentation rate were normal. However we should mention that in three of our cases there were from 5 to 6 million red cells per c.mm., i.e. a mild polycythæmia (a common red count in Barcelona being between $4 \cdot 3$ and 4.6 millions). The rest of the neurological examination was normal in all respects.

Radiographs of the skull were normal in all cases, and this is of some importance in the differential diagnosis in which the question of parasellar tumour and meningioma of the shenoidal ridge or tuberculum sellæ might arise. In two of our cases there were faint shadows which might have been interpreted as calcification in the internal carotid artery. In all of our cases there was observed in addition an increase of vascularization in the territory of the meningeal arteries, characterized by the dilatation of the bony channels of this artery.

Cerebral angiography may be very useful for the diagnosis of these lesions and Taptas affirms having found in his fourth case an enlargement of the anterior loop of the internal carotid, apparently in contact with the anterior clinoids. On the other hand the anatomical lesion found in one of our cases seems to show that this type of vascular dilatation may not always occur, and it is even possible that the injection may fail in some cases owing to obliteration of the vessel.

\section{Surgical Pathology}

The arterial lesion was in all of our cases macroscopically characterized by a segmentary enlargement of the internal carotid artery underneath the anterior clinoid and optic nerve, being generally bilateral (Fig. 4). The dilatation was roughly fusiform in all of our cases and more evident on one side (Fig. 4).

In one of them (the first) there seemed to be a perivascular or adventitial lesion of a particular character (Fig. 4A). The optic nerves seemed displaced upwards and either inwards or outwards by the enlargement of the artery, and in the first of our cases one of the nerves seemed notably atrophic and reduced in volume to about half its normal size (Fig. 4A). The compression of the nerves against the dorsal border of the roof of the optic channel was most evident in all the cases we operated upon (Figs. 4 A, B, C, D). In all these cases there were adhesions between the optic nerves and the base of the frontal lobes, constituting a true arachnoiditis which it was necessary to separate by sharp dissection in order to expose them.

In all our cases except the fourth, which was not verified, and the fifth, we thought that there was a parachiasmal lesion, e.g., suprasellar meningioma, in the first case because there were peripheral signs of Von Recklinghausen's disease. In the third case the diagnosis of neoplasm was excluded only after the ventriculogram. Cases 4 and 5 were successfully diagnosed on a clinical basis and the last was verified surgically. We did not use angiography, fearing the known risks in elderly people with diseased arteries and because we do not consider it absolutely necessary.

Except in our fourth case, which refused operation, all the others were surgically explored by the transfrontal route. In our first case a clip was placed in the anterior portion of the enlarged artery and the optic nerve was freed by unroofing the optical canal on the left side (Fig. 4A). In the second case, the left carotid was also clipped and the optic canal opened (Fig. 4B). In the third case, in view of the unhappy experience of the second, who died on the fourth post-operative day from cerebral softening, we limited ourselves to unroofing the optic canals (Fig. 4C) and in a second operation we proceeded to ligature the internal carotid artery in the neck. In the fifth case we limited ourselves to the removal of the roofs of the optic canals (Fig. 4D).

\section{Operative Results}

The operative results have been varied: in the first case a definite and enduring improvement was obtained, so much so that at the end of four months the acuity had improved from 5 per cent. to 10 per 
cent. (normal 1.0) though there was not much improvement in the visual fields (Fig. 3A).

In the second case death took place on the fourth post-operative day after clouding of consciousness and coma. The post-mortem examination showed

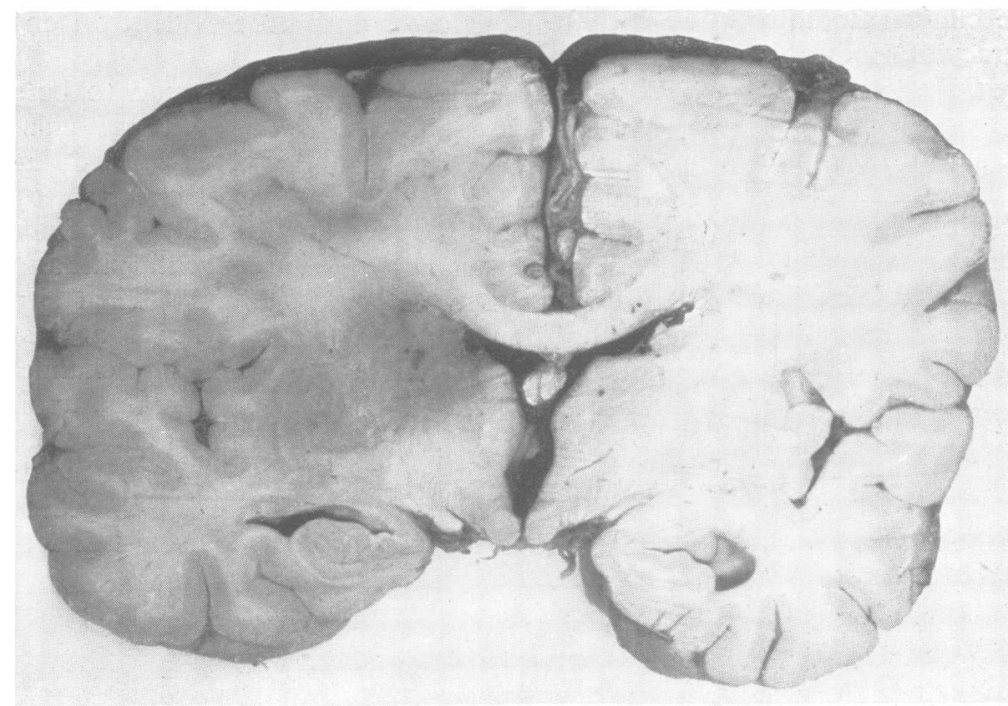

FIG. 7.-Coronal section of the brain in Case 3 showing the hæmorrhagic softening at the left basal ganglia. The ventricular cavities appeared partially filled with blood clots. the existence of an extensive area of softening in the basal ganglia of the left hemisphere (Fig. 7), with subpial and intraventricular hæmorrhage which we attributed at first to surgical obliteration of the carotid artery.

In the third case a cerebral ictus occurred with a contralateral hemiplegia six days after the ligature of the internal carotid in the neck, and we want to stress that the ligature had been preceded in this case by progressive compressions according to the method of Matas, reaching 30 minutes of well tolerated manual occlusion. The patient was convalescent from typhoid fever which began when she had already entered the hospital and caused us to postpone the operation until complete recovery. The ictus was attributed to an ascending thrombosis, and at present the patient is on the way to recovery. The fifth case has been operated upon so recently 2 that it is not yet possible to 8 judge the result.

\begin{tabular}{|c|c|c|c|c|c|c|}
\hline No. & $\begin{array}{l}\text { Author } \\
\text { Case } \\
\text { Date }\end{array}$ & $\begin{array}{c}\text { Age } \\
\text { and Sex }\end{array}$ & $\begin{array}{l}\text { Duration } \\
\text { of Symptoms }\end{array}$ & Symptoms & $\begin{array}{l}\text { Visual Acuity and fields } \\
\text { R.: right. L. : left }\end{array}$ & 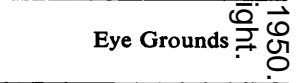 \\
\hline 1 & $\begin{array}{l}\text { Adson } \\
\text { Case } 6 \\
1942\end{array}$ & $\stackrel{49}{F}$ & 4 months & $\begin{array}{c}\text { Rapid loss of vision in both } \\
\text { eyes }\end{array}$ & $\begin{array}{c}\text { R.: } 6 / 12 \text {. } \\
\text { Litemporal hemianopsia } 3 / 30\end{array}$ & $?$ \\
\hline 2 & $\begin{array}{l}\text { Adson } \\
\text { Case } 7 \\
1842\end{array}$ & $\begin{array}{l}31 \\
\mathbf{M}\end{array}$ & 2 months & Ditto & $\begin{array}{l}\text { R.: } 14 / 89 . \text { L. : } 14 / 141 \\
\text { Bilateral large central sectoma }\end{array}$ & Bilateral atrophy \\
\hline 3 & $\underset{1944}{\text { Tassman }}$ & $\mathbf{F}$ & 8 months & Loss of vision in left eye & R. : good. L. : 0 & $\begin{array}{l}\text { R.: Stasis } \\
\text { L.: Atrophy }\end{array}$ \\
\hline 4 & $\begin{array}{c}\text { Taptas } \\
\text { Case } 4 \\
1948\end{array}$ & $\begin{array}{l}44 \\
\mathbf{M}\end{array}$ & 5 years & $\begin{array}{l}\text { Blurring of vision in right eye ; } \\
\text { later in left eye }\end{array}$ & R. : 0. L. : $1 / 5$ & 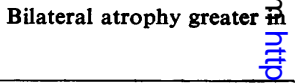 \\
\hline 5 & $\begin{array}{l}\text { Ley } \\
\text { Case } 1 \\
1945\end{array}$ & $\begin{array}{l}45 \\
\mathbf{M}\end{array}$ & 9 years & $\begin{array}{l}\text { Loss of vision in left eye, then } \\
\text { rapidly in right eye }\end{array}$ & $\begin{array}{l}\text { R. : } 0.2 \text {. L.: } 0.05 \\
\text { Large defect in lower } L . \text { con- } \\
\text { centric reduction } R \text {. }\end{array}$ & R. : Stasis. L. : Atraphy \\
\hline 6 & $\begin{array}{l}\text { Ley } \\
\text { Case } 2 \\
1947\end{array}$ & $\begin{array}{l}54 \\
\mathbf{M}\end{array}$ & 1 year & Ditto & R.: $1 / 6 . \quad$ L. : $1 / 20$ & Ditto \\
\hline 7 & $\begin{array}{l}\text { Ley } \\
\text { Case } 3 \\
1948\end{array}$ & $\begin{array}{l}54 \\
F\end{array}$ & 16 years & $\begin{array}{l}\text { Loss of vision in right eye, then } \\
\text { rapidly in left eye }\end{array}$ & $\begin{array}{r}\text { R. : }: \begin{array}{l}0.2 . \quad \text { L. : } 0.06 \\
\text { Extensive lower defect }\end{array} \text { R. } \\
\text { Island of vision temporal field } L\end{array}$ & R. : Atrophy. L. : St高is \\
\hline 8 & $\begin{array}{c}\text { Ley } \\
\text { Case } 4 \\
1948\end{array}$ & $\begin{array}{l}56 \\
\mathbf{M}\end{array}$ & 1 month & $\begin{array}{c}\text { Rapid loss of vision in lower } \\
\text { part left eye }\end{array}$ & $\begin{array}{c}\text { R.: } 1 . \quad \text { L. : } 1 / 2 \\
\text { Quadrantic defect lower nasal L. }\end{array}$ & $\begin{array}{l}\text { R. : Normal. L.: S祭 } \\
\text { and atrophy }\end{array}$ \\
\hline 9 & $\begin{array}{c}\text { Ley } \\
\text { Case } 5 \\
1949\end{array}$ & $\mathbf{F 3}$ & 2 years & $\begin{array}{l}\text { Loss of vision temporal field : } \\
\text { right eye, then in both eyes }\end{array}$ & $\begin{array}{l}\text { R. : } 0.05 . \text { L. : } 0.6 \\
\text { lower horizontal hemianopsia }\end{array}$ & $\begin{array}{l}\text { Atrophy upper halves botl } \\
\text { discs and odema in the lotre }\end{array}$ \\
\hline
\end{tabular}




\section{Symptomatology}

In Table I we have grouped the symptomatology, the operative findings, and the evolution of our five cases and those of the four others that we have been able to collect from the literature. From a study of the table, it seems possible to summarize the syndrome produced by the segmentary enlargement of the intracranial carotid as follows. It appears in middle age, especially between 44 and 56 years and rather more often in the male sex, with mild arterial hypertension, but with normal or only slightly impaired renal function, moderate arterio-sclerosis and polycythæmia. The visual symptomatology is of long duration and usually unilateral at the beginning, characterized by "optic neuritis" and reduced acuity, followed after a variable time (which may be considerable) by impairment of the other eye. In time the typical Foster-Kennedy syndrome may occur. As far as the visual fields are concerned, there are irregular defects with a marked tendency to reductions of the concentric type, especially in the lower part of the fields, even leading to horizontal hemianopsia. The visual symptoms are usually accompanied by slight headaches, predominately frontal and orbital, and occasionally peripheral vasomotor changes may occur. The neurological examination is always negative as regards objective signs, and the oculomotor nerves are not affected except when there exist other alterations in the more proximal portions of the vessel. In no case was there increased intracranial pressure.

The radiological examination usually reveals calcifications in the Gruber ligaments (Figs. 8 and 9), and less frequently in the falx or frontal bones. A

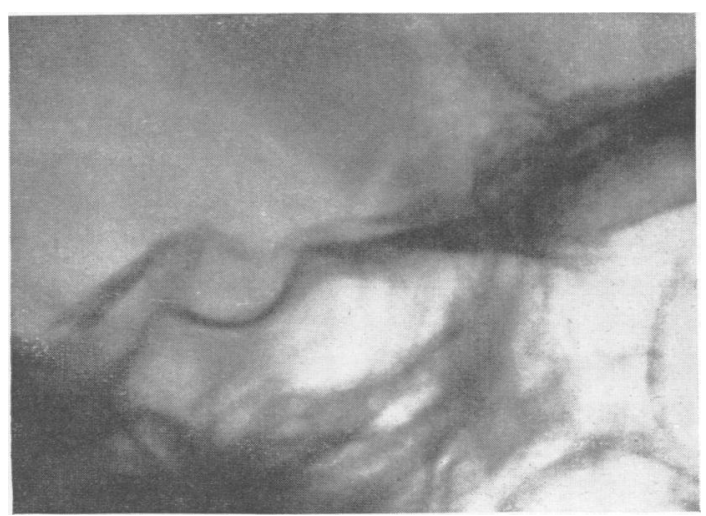

FIG. 8.-Radiograph of the sella turcica in Case 1 showing a marked calcification of the Grüber ligaments as well as of the diaphragma sella.

dilatation of the bony channels of the middle meningeal arteries is commonly observed. The existence of slight shadows corresponding to the subclinoid portion of the carotid is questionable.

\begin{tabular}{|c|c|c|c|c|c|}
\hline $\begin{array}{l}\text { Blood } \\
\text { Pressure } \\
\text { (nim. Hg.) }\end{array}$ & $\begin{array}{c}\text { Renal } \\
\text { Function }\end{array}$ & Other Symptoms & Radiograph Findings & Type of Operation & Results \\
\hline Normal & Normal & - & Sella turcica normal & Unroofing of optic channels & Much improved \\
\hline$\frac{140}{90}$ & Normal & $\begin{array}{l}\text { Headaches, nephrectomy, } \\
\text { cranial trauma }\end{array}$ & $\begin{array}{l}\text { Falx and frontal } \\
\text { calcifications }\end{array}$ & Ditto & Unchanged \\
\hline$?$ & $?$ & Headaches & $?$ & "Exploratory" & $?$ \\
\hline$?$ & $?$ & $\begin{array}{l}\text { Paroxysmal headaches, vaso- } \\
\text { motor changes, cranial trauma }\end{array}$ & $\begin{array}{c}\text { Angiography : Enlarge- } \\
\text { ment anterior loop of } \\
\text { intercranial carotid }\end{array}$ & Ditto & Improved \\
\hline$\frac{128}{84}$ & Normal & $\begin{array}{l}\text { Dizziness, paræsthesia cu- } \\
\text { taneous Recklinghausen, } \\
\text { cranial trauma }\end{array}$ & $\begin{array}{c}\text { Calcification Grüber } \\
\text { ligaments, diploic } \\
\text { Hypervascularization } \\
\text { (Fig. 8) }\end{array}$ & $\begin{array}{l}\text { Clipping of left intracranial } \\
\text { carotid ; unroofing of } \\
\text { left optic canal }\end{array}$ & Ditto \\
\hline$\frac{155}{80}$ & Normal & $\begin{array}{l}\text { Headaches, paræsthesia, } \\
\text { congenital convergent squint } \\
\text { in left eye }\end{array}$ & Normal & $\begin{array}{l}\text { Clipping of left intracranial } \\
\text { carotid ; unroofing of both } \\
\text { optic canals }\end{array}$ & $\begin{array}{c}\text { Death four days after opera- } \\
\text { tion due to cerebral } \\
\text { softening }\end{array}$ \\
\hline$\frac{175}{90}$ & Diminished & Headaches & $\begin{array}{l}\text { Calcification Grüber } \\
\text { ligaments. } \\
\text { hypervascularization }\end{array}$ & $\begin{array}{l}\text { Unroofing of optic channel } \\
\text { and ligature of internal } \\
\text { carotid in the neck }\end{array}$ & $\begin{array}{l}\text { Right hemiplegia due to } \\
\text { ascending thrombosis which } \\
\text { appeared } 6 \text { days after the } \\
\text { ligature }\end{array}$ \\
\hline$\frac{190}{100}$ & Normal & Ditto & Normal & Refused & $\begin{array}{l}\text { Symptoms progressing in } \\
\text { both eyes }\end{array}$ \\
\hline$\frac{195}{100}$ & Diminished & Slight hyperglycæmia & Normal & $\begin{array}{l}\text { Unroofing both optic } \\
\text { canals }\end{array}$ & $\begin{array}{l}\text { Operation too recent to } \\
\text { judge }\end{array}$ \\
\hline
\end{tabular}




\section{Diagnosis}

The differential diagnosis must be made between the parasellar meningiomas, particularly those of the lesser wing of the sphenoids, the pituitary

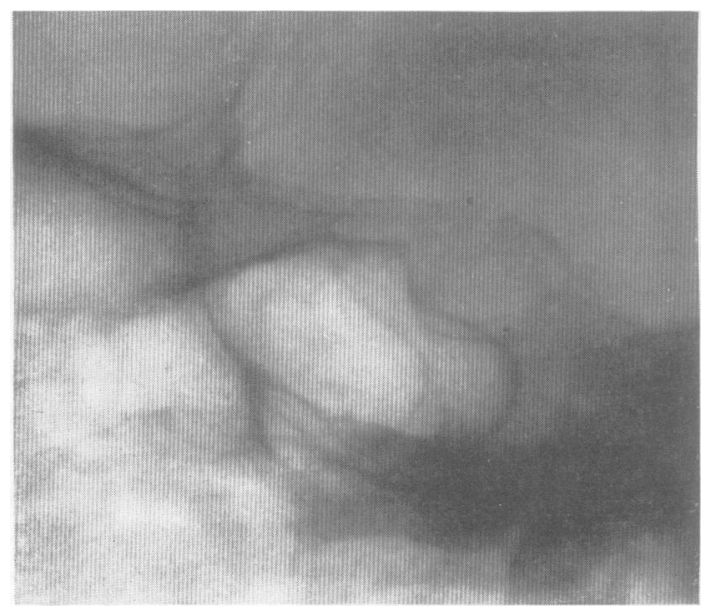

FIG. 9.-Radiograph of the sella turcica in Case 3 showing a mild calcification of the Grüber ligaments

adenomas, craniopharyngiomas, gliomas of the chiasma, the congenital saccular aneurysms, and the so-called " opto-chiasmatic arachnoiditis."

Meningioma.-Meningiomas of the lesser wing of the sphenoid are seen only in women and generally at an early age : exophthalmos is common. There are in nearly all such cases very characteristic radiological findings.

Pituitary Adenoma. - With regard to the pituitary adenomas, these do not generally offer diagnostic difficulties, because the lesions we are discussing lack the endocrine and radiological signs so characteristic of these tumours. The craniopharyngiomas usually occur in younger subjects. There is seldom a Foster-Kennedy syndrome, and the absence of hypothalamic disturbance and symptoms of increased intracranial tension is common. Finally, the radiological findings are usually very different, especially in relation to craniopharyngiomas, which often show suprasellar calcifications and signs of increased intracranial pressure.

Glioma of the Chiasma.-The gliomas of the chiasma may cause confusion especially when, as in our first case, there exist cutaneous signs of Von Recklinghausen's disease, but the visual symptoms are usually more severe in the gliomas, with an early effect on the central vision. The alterations in the visual fields are generally different but more important ; the optic canal is usually markedly enlarged when seen on $x$-ray examination.

Saccular Aneurysm.-So far as the congenital saccular aneurysms are concerned, the diagnosis can be established by the absence of subarachnoid hæmorrhages and of impairment of the oculomotor and trigeminal nerves and also by the angiographic picture.

Optochiasmatic Arachnoiditis.-The diagnosis from the so-called "optochiasmatic arachnoiditis" is not so simple, but one must take into account the great confusion prevailing about this condition, the pathology of which does not seem, as yet, well defined, and to which is attributed today a large proportion of the optic atrophies. However, if we take into account the clinical picture attributed to that condition, we shall say that in arachnoiditis both optic nerves are usually affected from the beginning, the progression of the symptoms is more uniform, the alterations of the visual fields are less definite, and macular vision is early affected. In addition, the subjective troubles of the patients are usually less acute and they seldom show arterial hypertension. In either case surgical exploration seems to be equally indicated, even though the results obtained in cases of arachnoiditis have been, in our experience, unsatisfactory.

\section{Aetiology and Pathology}

The opportunity which we had in our second case of making a post-mortem examination has permitted us to demonstrate not only the histological nature of the arterial lesion under discussion but also to make clearer its ætiology.

The abnormal segmentary enlargement of the artery was found to be due not to an actual dilatation, as we had been led to believe from its external aspect (Figs. 5 and 6A), but on the contrary its lumen was found to be almost totally obliterated, and there were changes in the vessel wall (Fig. 6B) which indicated a lesion much more complicated than we had supposed.

The histological examination (carried out by Dr. C. Oliveras de la Riva) also revealed that we were not dealing with simple atheromatous lesions of the arterial wall as Adson (1942) believed, but with complicated lesions which, at least in part, seemed to point to congenital abnormalities of the arterial wall.

Pathological Description.-Both internal carotid arteries in their intracavernous and subclinoidal portion appeared dilated, the left being more accentuated (Figs. 5 and 6A). The dilatation was not 


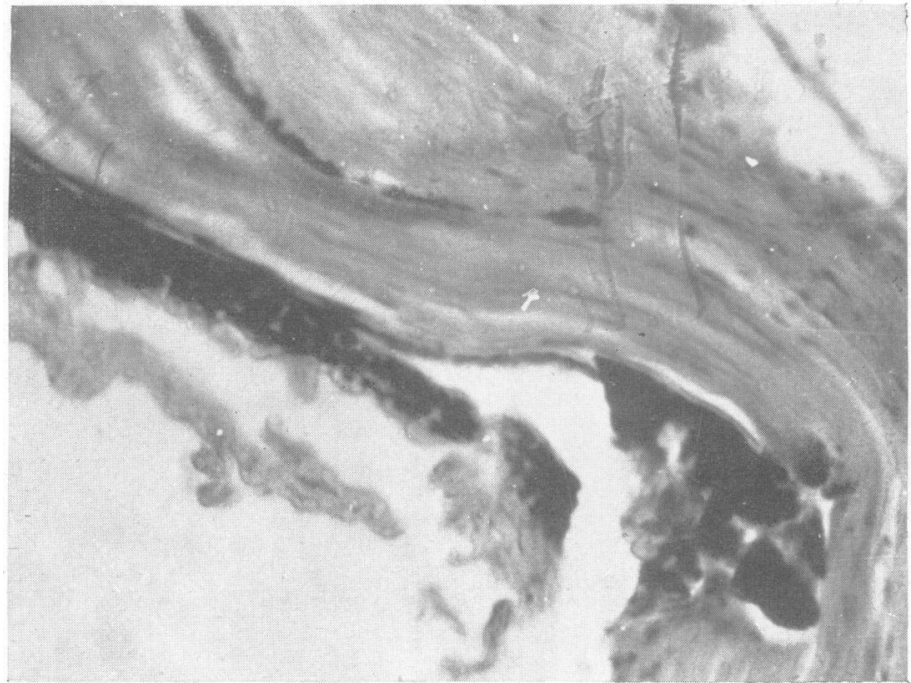

Fig. 10.-Transverse section of the arterial wall in Case 2 showing atrophy of the media with marked thinning of the muscularis, and necrosis with calcareous infiltration of the intima.

so fusiform as it seemed at first glance, for there were multiple small dilatations, and on examining the divided vessel, the wall showed an irregular appearance with formation of folds and cavities (Fig. 6B). The walls of the arteries were thin and flaccid, being easily collapsible and with a venous appearance. Atheromatous deposits could not be felt.

Microscopic Description.-The alterations which we found in the arterial wall were of two types. (1) There was a myodystrophic alteration of the media of varied intensity and distribution (hypoplasia) which showed itself by a marked thinning of the muscularis and elastica, which could hardly be identified in some places where they were replaced by a fibrous connective tissue (Fig. 10). (2) The intima showed marked changes also, consisting of thickening, splitting, and hyalinosis of the internal elastica (Fig. 11). There were places where one could see actual necrosis with calcareous infiltration of the intima (Fig. 10.)

From these findings we may deduce that the lesion of the media is congenital and due to hypoplasia of the muscularis. The wall of the artery seems to expand owing to the abnormal increase in the blood pressure. Secondarily, the intima degenerates and hyalinosis and calcification take place.

The left optic nerve was also studied. It was found to be flattened and markedly reduced in size. By using the silver nitrate technique and Spielmeyer method, degenerative lesions of the nerve fibres affecting the myelin sheath were also seen.

The pathological diagnosis was one of congenital hypoplasia of the media with secondary degeneration of the intima (hyalinosis and calcification).

\section{Discussion}

Saphir (1935) in a work cited by Taptas has published three necropsy examinations of individuals aged more than 60 years who died from acute vascular accidents in which the carotid lesions seem to have been similar to those we observed. Therefore we believe that from the pathogenic point of view, one must admit the existence in these cases of a primordial factor consisting of a congenital anomaly of the intracranial carotid that may be segmentary or diffuse. This seems opposed to the pathogenic conception of Taptas, according to whom the fundamental causes were of a vasomotor character, (active vasodilatation by abnormal parasympathetic stimulation). Taptas' ingenious pathogenic conception lacks pathological or experimental

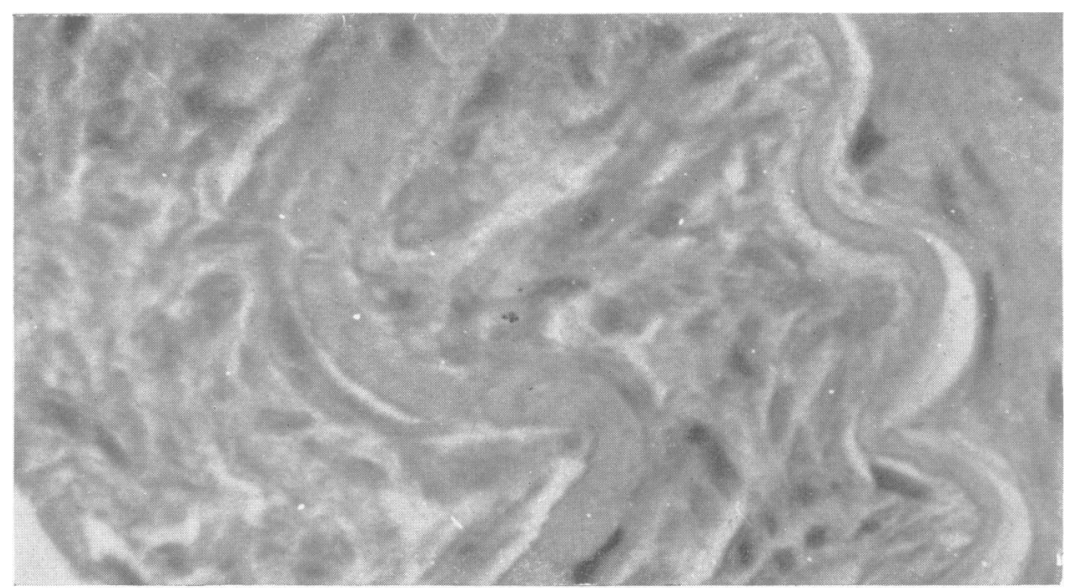

FIG. 11.-High-power microphotograph of the intima showing the thickening, splitting, and hyalinosis of the internal elastica (" elastosis " and " hyalinosis "). 
evidence. However, it is possible that vasomotor disturbances play an important part as a releasing mechanism of the condition. It would explain the influence of injury recorded in three of the nine cases. It is also possible that the general arterial hypertension, which is common in these cases, is an additional factor.

Perhaps the pathological examination does not justify the use of the term " aneurysm" which we have given to these lesions, but it is convenient to describe them as "fusiform aneurysms" to distinguish them from the congenital saccular type, and from the serpentine type, such as were observed in our second case and in those of Saphir and Taptas, in which the lesions were more extensive affecting the whole or a great part of the intracranial carotid.

To evaluate the operative results in this condition is difficult since we lack details of the operations practised in the cases of Tassman and Taptas. In three of our cases, besides the unroofing of the optic canal as in Adson's two cases, we also obliterated the carotid arteries either by clipping them intracranially or by ligature in the neck (Case 3).

These operations on the carotid arteries seem to have been harmful for in two of the three cases they produced grave cerebral complications, with the death of one of the patients. In any event, if we consider the pathology, surgical obliteration of the carotid is not called for, since the apparent enlargement is not due to an arterial dilation, but to a complex alteration of structure with almost complete obliteration of the lumen.

From our experience, we consider that the operative results are sufficiently promising in selected cases, and think that the operation should be limited to freeing the optic nerves by means of unroofing the optic canals and opening their dural sheaths. Finally it is to be expected that, as Adson has observed, results should be more satisfactory when the operation is performed in the early stages, when the degree of atrophy of the optic nerves is less severe.

I am deeply indebted to my colleagues Drs. J. and J. I. Barraquer, Julian Gil, Armas del Rosario, and Hernandez Guerra who furnished me with the clinical material of this report.

I want also to express my acknowledgment to $\mathrm{Mr}$. Joe Pennybacker for his great kindness in reading the manuscript as well as for his valuable suggestions and advice.

\section{REFERENCES}

Adson, A. W. (1942). Trans. Amer. Acad. Ophthalm. Otolaryng., 46, 95.

Malbran; J." (1936). "Campo Visual." El Ateneo. Buenos Aires.

Moniz, E. (1934). “ L'Angiographie Cérébrale.” Masson et Cie. Paris.

Saphir, O. (1935). Arch. Path., 20, 36. Cited by Taptas, loc. cit.

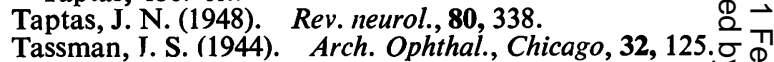

Traquair, H. M. (1942). "An Introduction to Clinical 응 Perimetry." Henry Kimpton. London. 